\title{
Upaya Meningkatkan Hasil Belajar Siswa dengan Media Flashcard pada Materi An-Nazah di DTA Manaarul Huda Kelas IV
}

\author{
Ahmad Fajar ${ }^{1}$ \\ Devi Kurniawati ${ }^{2}$
}

DOI: https://doi.org/10.52593/klm.02.1.02

Naskah diterima: 12-01-2021, direvisi: 22-01-2021, disetujui: 25-01-2021

\begin{abstract}
Abstraksi
Permasalahan pada penelitian ini bersumber dari a) belum adanya guru lulusan Bahasa Arab di sekolah b) siswa memandang bahwa pelajaran Bahasa Arab adalah pelajaran yang rumit. Penelitian ini bertujuan untuk meningkatkan: 1) aktivitas belajar siswa dalam pembelajaran Bahasa Arab; dan 2) hasil belajar siswa dalam pembelajaran Bahasa Arab materi An-Nazah bagi siswa kelas IV DTA Manaarul Huda Kecamatan Cipeundeuy Subang tahun pelajaran 2019/2020 melalui penerapan media Flashcard. Penelitian ini merupakan penelitian tindakan kelas. Penelitian dilakukan di MDTA Manaarul Huda Desa Wantilan Kecamatan Cipeundeuy Kabupaten Subang selama dua bulan. Subjek penelitian adalah siswa kelas IV DTA Manaarul Huda Desa Wantilan Kecamatan Cipeundeuy Kabupaten Subang tahun pelajaran 2019/2020 yang terdiri dari 22 orang siswa. Objek dalam penelitian ini adalah pembelajaran Bahasa Arab materi An-Nazah dengan penerapan media flashcard. Penelitian ini menyimpulkan bahwa: 1) Penerapan media Flashcard dapat meningkatkan aktivitas belajar siswa dalam pembelajaran Bahasa Arab. Hal ini ditunjukkan dengan meningkatnya aktivitas belajar siswa pada setiap siklus tindakan yang dilakukan; dan 2) Penerapan media Flashcard dapat meningkatkan hasil belajar siswa dalam pembelajaran Bahasa Arab materi An-Nazah bagi siswa kelas IV DTA Manaarul Huda Wantilan Cipeundeuy Subang tahun pelajaran 2019/2020. Hal ini ditunjukkan dengan meningkatnya tingkat ketuntasan belajar siswa pada setiap siklus tindakan yang dilakukan.
\end{abstract}

Kata kunci : Aktivitas, Flashcard, Pembeajaran Bahasa Arab.

\section{A. PENDAHULUAN}

Pembelajaran Bahasa Arab di sekolah harus efektif dan sesuai dengan ketertarikan siswa terhadap metode atau media yang dipakai oleh guru. Dengan penggunaan metode dan media yang tepat maka pembelajaran akan lebih diterima oleh siswa, sehingga siswa bisa lebih mudah memahami pelajaran yang disampaikan oleh guru. Seperti proses belajar mengajar pada umumnya, belajar mengajar Bahasa Arab memiliki faktor-faktor yang mempengaruhi proses pembelajarannya. Di antara faktorfaktor tersebut, tentu ada yang memberi pengaruh positif terhadap belajar mengajar bahasa, ada pula yang memberikan pengaruh negatif. Aspek-aspek tersebut meliputi

\footnotetext{
${ }^{1}$ Dosen STAI Dr. KHEZ. Muttaqien Purwakarta, ahmadfajar2292@gmail.com.

${ }^{2}$ Mahasiswi STAI Dr. KHEZ. Muttaqien Purwakarta, devikurnia080@gmail.com.
} 
aspek motivasi, aspek usia, aspek penyajian formal, aspek bahasa pertama, dan aspek lingkungan. ${ }^{3}$

Beberapa kendala pembelajaran bahasa Arab di lapangan antara lain: Pertama, belum adanya guru lulusan Bahasa Arab di sekolah, sehingga guru kesulitan untuk mengolah metode dan media pada pembelajan. Kedua, siswa memandang bahwa pelajaran Bahasa Arab adalah pelajaran yang rumit, tidak menyenangkan, sehingga kurangnya minat mempelajari Bahasa Arab. Tugas-tugas terstruktur yang diberikan dikerjakan secara tidak serius dan seadanya, sekedar memenuhi formalitas.

Pada siswa kelas IV DTA Manaarul Huda Cipeundeuy Subang Tahun pelajaran 2019/2020 siswa beranggapan bahwa pelajaran bahasa Arab rumit dan tidak menyenangkan. Sehingga berakibat pada hasil belajar yang rendah.

Dengan permasalahan di atas, guru perlu melakukan perbaikan pmbelajaran dengan focus mendorong siswa lebih aktif terlibat dalam proses pembelajaran. Dengan siswa terlibat secara aktif, maka pembelajaran akan menjadi lebih menyenangkan, friendly, dan menghasilkan pengetahuan secara lebih baik.

Usaha perbaikan yang dilakukan oleh guru adalah dengan menerapkan media flashcard pada siswa. Media flashcard adalah media yang membuat suasana belajar menyenangkan, tidak formal namun tidak mengurangi esensi dari pembelajaran itu sendiri. Ditambah siswa DTA Manaarul adalah anak usia dibawah 13 tahun. Suatu kondisi anak-anak yang masih menyukai dunia bermain. Sehingga media flashcard cocok diterapkan.

Permainan flashcard merupakan permainan yang mengarah pada kognitif sehingga mengembangkan krativitas anak. Walaupun dianggap media belajar yang murah, praktis dan mudah dibuat namun media gambar ini diyakini dapat menarik perhatian anak. Sehingga anak menjadi lebih focus dalam menyimak pembalajaran. ${ }^{4}$

Sesuai dengan latar belakang yang telah dipaparkan diatas, selanjutnya dirumuskan permasalahan sebagai berikut:

1. Apakah penerapan media flashcard dapat meningkatkan aktivitas belajar siswa dalam pembelajaran Bahasa Arab?

\footnotetext{
${ }^{3}$ Acep Hermawan, Metodologi Pembelajaran Bahasa Arab (Jakarta: Rosda, 2008), 5.

${ }^{4}$ Drs Ahmad Susanto, M.Pd, Perkembangan Anak Usia DIni (Jakarta: Kencana, 2012), 130.
} 
Kalamuna, Vol. 2. No. 1 Januari 2021. $24-36$

2. Apakah penerapan media flashcard dapat meningkatkan hasil belajar siswa dalam pembelajaran Bahasa Arab materi An-Nazah bagi siswa kelaas IV DTA Manaarul Huda Cipeundeuy Subang tahun ajaran 2019/2020?

Berdasarkan perumusan masalah diatas, maka tujuan yang dilakukan dalam penelitian ini adalah:

1. Untuk meningkatkan aktivitas belajar siswa dalam pembelajaran Bahasa Arab melalui media flashcard.

2. Untuk meningkatkan hasil belajar siswa dalam pelajaran Bahasa Arab materi An-Nazah bagi siswa kelaas IV DTA Manaarul Huda Cipeundeuy Subang tahun ajaran 2019/2020 melalui media flashcard.

PTK bermanfaat bagi guru, pembelajaran/siswa, serta bagi sekolah. Manfaat PTK bagi guru adalah membantu guru memperbaiki pembelajaran, membantu guru berkembang secara professional, meningkatkan rasa percaya diri guru dan meningkatkan guru secara aktif mengembangkan pengetahuan dan keterampilan.

Bagi pembelajar/siswa, PTK bermanfaat untuk meningkatkan aktivits belajar, hasil belajar dan bersikap kritis terhadap hasil belajarnya.

Bagi sekolah, PTK membantu sekolah untuk berkembang karena adanya peningkatan/kemajuan pada diri guru dan pendidikan di sekolah tersebut. ${ }^{5}$

\section{B. LANDASAN TEORI}

\section{a. Media Flashcard}

Flashcard adalah media pembelajaran dalam bentuk kartu bergambar yang berukuran $25 \times 30 \mathrm{~cm}$. Gambar-gambarnya dibuat menggunakan tangan atau foto, atau memanfaatkan gambar atau foto yang sudah ada yang di tempelkan pada lembaranlembaran flashcard. ${ }^{6}$

Dari uraian tersebut dapat dikatakan bahwa flashcard merupakan media yang berbentuk kartu bergambar yang dibuat dengan menggunakan foto atau gambar, pada bagian belakang terdapat keterangan dari gambar yang ada pada pada flashcard tersebut. Dari kutipan tersebut dijelaskan ukuran flashcard 25 x30 cm.

${ }^{5}$ Drs. Zainal Aqib, M.Pd., Drs. M. Maftuh, Sujak, S.Pd.,M.Pd., Drs. Kawentar, Penelitian Tindakan Kelas untuk guru SMP, SMA, SMK (Bandung: CV. Yrama Widya, 2011), 4.

${ }^{6}$ Drs. Rudi Susilana, M.Si, Cepi Riyana, M,Pd Media Pembelajaran (Bandung: CV Wacana Prima, 2009), 95. 
Sedangkan menurut pendapat lain "Flashcard biasanya berukuran 8 x $12 \mathrm{~cm}$ atau dapat disesuaikan dengan besar kecilnya kelas yang dihadapi, kartu-kartu tersebut berisi gambar-gambar (binatang, benda, buah-buahan dansebagainya) dapat digunakan untuk melatih mengeja dan memperkaya kosakata". ${ }^{7}$

Berdasarkan pendapat diatas, dapat dijelaskan bahwa ukuran flashcard adalah 8 $\mathrm{x} 12 \mathrm{~cm}$ atau biasa disesuaikan dengan keadaan siswa yang dihadapi, apabila jumlah siswa banyak maka flashcard dibuat dengan ukuran yang lebih besar dan jika jumlah siswa sedikit maka flashcard dibuat dengan ukuran kecil. Selain pendapat diatas, Flashcard merupakan alat peraga dari koran berukuran 18 x 16 inci yang dibubuhi gambar-gambar menarik, kata, ungkapan, atau kalimat. ${ }^{8}$

Menurut Suryana Flashcard merupakan salah satu bentuk permainan edukatif berupa kartu-kartu yang memuat gambar dan kata yang sengaja dirancang oleh doman untuk meningkatkan berbagai aspek diantaranya: mengembangkan daya ingat, melatih kemandirian dan meningkatkan jumlah kosakata."

Dari beberapa pengertian diatas dapat disimpulkan bahwa flashcard adalah salah satu bentuk media edukatif berupa kartu yang memuat gambar dan kata yang ukurannya bisa disesuaikan dengan siswa yang dihadapi dan untuk mendapatkannya bisa membuat sendiri atau menggunakan yang sudah jadi. Media ini merupakan media pembelajaran yang dapat membantu dalam meningkatkan berbagai aspek seperti: mengembangkan daya ingat, melatih kemandirian dan meningkatkan jumlah kosakata.

Terlebih dalam pembelajaran Bahasa Arab yang terkesan sulit, rumit dan tidak menyenangkan, dengan adanya media flashcard ini akan menggugah motivasi peserta didik untuk mengikuti pembelajaran Bahasa Arab. Media Flashcard juga membuat peserta didik tertarik sehingga konsentrasinya tetap focus pada pembelajaran.

\section{Kelebihan Media Flashcard}

Media flashcard tergolong dalam media visual (gambar), media flashcard memiliki beberapa kelebihan, antara lain:

\footnotetext{
${ }^{7}$ Prof Dr. Azhar Arsyad, M.A, Media Pembelajaran (Jakarta: Rajawali, 2017), 85. 2009), 176

${ }^{8}$ Dr. H Ahmad Izzan, M.Ag, Metodologi Pembelajaran Bahasa Arab (Bandung: Humaniora,

${ }^{9}$ Permadi, D. dan Suryana, N. Pendekatan, Metode, Tehnik dan ModelPembelajaran Bahasa Inggris di SD dan MI (Bandung: Sarana Panca Karya, 2000), 24.
} 
1. Mudah dibawa kemana-mana; yakni dengan ukuran yang kecil flashcard dapat disimpan di tas bahkan di saku, sehingga tidak membutuhkan ruang yang luas, dapat digunakan di mana saja, di kelas ataupun di luar kelas.

2. Praktis; yakni dilihat dari cara pembuatannya dan penggunaannya, media flashcard sangat praktis, dalam menggunakan media ini guru tidak perlu memiliki keahlian khusus, media ini tidak perlu juga membutuhkan listrik. Jika akan menggunakannya kita tinggal menyusun urutan gambar sesuai dengan keinginan kita, pastikan posisi gambarnya tepat tidak terbalik, dan jika sudah diguanakan tinggal disimpan kembali dengan cara diikat atau menggunakan kotak khusus supaya tidak tercecer.

3. Gampang diingat; kombinasi antara gambar dan teks cukup memudahkan siswa untuk mengenali konsep sesuatu, untuk mengetahui nama sebuah benda dapat dibantu dengan gambarnya, begitu juga sebaliknya untuk mengetahui nama sebuah benda atau konsep dengan melihat hurufnya atau teksnya.

4. Menyenangkan; media flashcard dalam penggunaannya dapat melalui permainan. Misalnya siswa secara berlomba-lomba mencari suatu benda atau nama-nama tertentu dari flashcard yang disimpan secara acak, dengan cara berlari siswa berlomba untuk mencari sesuatu perintah. ${ }^{10}$

Berdasarkan uraian di atas, dapat disimpulkan bahwa kelebihan media flashcard antara lain: mudah dibawa, praktis, gampang diingat dan menyenangkan. Selain itu media flashcard dapat membantu kemampuan otak kanan untuk mengingat gambar dan kata-kata sehingga dapat meningkatkan perbendaharaan kata siswa.

\section{b. Hasil Belajar}

Menurut Sardiman menyatakan bahwa hasil belajar adalah adanya perubahan tingkah laku dalam dirinya. Perubahan tingkah laku tersebut menyangkut baik perubahan yang bersifat pengetahuan (kognitif), keterampilan (psikomotor) maupun yang menyangkut nilai dan sikap (afektif). Oleh karena itu, apabila siswa mempelajari pengetahuan tentang konsep, maka perubahan perilaku yang diperoleh adalah tidak hanya berupa penguasaan konsep tetapi juga keterampilan dan sikap.

${ }^{10}$ Drs. Rudi Susilana, M.Si, Cepi Riyana, M,Pd, Media Pembelajaran (Bandung: CV Wacana Prima,2009), 94. 
Sedangkan pengertian prestasi belajar menurut Maslow Prestasi belajar suatu masalah yang bersifat perenial dalam sejarah kehidupan manusia karena sepanjang rentang kehidupan manusia selalu mengejar prestasi menurut bidang dan kemampuan masing-masing kehadiran prestasi belajar dalam kehidupan manusia pada tingkat dan jenis tertentu pula manusia yang berada di bangku sekolah.

Berdasarkan beberapa pendapat di atas, mengambarkan bahwa hasil belajar merupakan proses perubahan tingkah laku yang meliputi pengetahuan, sikap dan keterampilan yang merupakan hasil dari aktivitas belajar yang ditunjukkan dalam bentuk angka-angka seperti yang dapat dilihat pada nilai rapor. Hasil belajar juga diartikan sebagai tingkat penguasaan yang dicapai oleh siswa dalam mengikuti proses pembelajaran sesuai dengan program pendidikan yang ditetapkan.

Tinggi atau rendahnya prestasi belajar siswa dipengaruhi oleh berbagai faktor. Faktor-faktor termaksud akan selalu ada sepanjang proses belajar mengajar. Faktorfaktor yang mempengaruhi prestasi belajar sebagai berikut:

a. Faktor dari luar, meliputi: lingkungan dan instrumental.

b. Faktor dari dalam, meliputi: fisiologis, psikologis, kecerdasan, motivasi, dan kemampuan kognitif.

\section{METODE PENELITIAN}

\section{Setting Penelitian}

Penelitian ini dilaksanakan di MDTA Manaarul Huda Desa Wantilan Kecamatan Cipeundeuy Kabupaten Subang. Penelitian ini dilaksanakan pada semester genap selama 3 bulan, yaitu mulai bulan Mei, Juni sampai bulan Juli 2020. Pemilihan waktu ini disesuaikan dengan alokasi waktu yang sudah ditetapkan dengan materi An-Nazah di semester genap.

Yang menjadi subjek pada Penelitian Tindakan Kelas (PTK) ini adalah seluruh siswa dan siswa MDTA Manaarul Huda kelas IV yang berjumlah 22 orang, terdiri dari 15 siswa perempuan dan 7 orang siswa laki-laki. Sumber data penelitian ini diperolah dari: Siswa, yaitu siswa dan siswi MDTA Manaarul Huda kelas IV dan Kepala Sekolah, yaitu Kepala Sekolah MDTA Manaarul Huda.

\section{Sumber Data}


Kalamuna, Vol. 2. No. 1 Januari 2021. $24-36$

Sumber dalam Penelitian Tindakan Kelas ini adalah siswa kelas IV DTA Manaarul Huda Semester II Tahun Pelajaran 2019/2020 yang berjumlah 22 orang siswa. Sumber berikutnya yaitu guru Bahasa Arab DTA Manaarul Huda kelas IV dan kepala sekolah DTA Manaarul Huda. Alasan pemilihan subjek didasari adanya fakta bahwa kelas tersebut mempunyai ketuntasan belajar yang rendah dalam pelajaran Bahasa Arab khususnya pada materi "An-Nazah".

\section{Teknik Pengumpulan Data}

Teknik yang digunakan untuk pengumpulan data dalam penelitian tindakan ini adalah teknik tes, observasi, dan dokumen.

1) Tes

Tes adalah serentetan pertanyaan/latihan soal yang digunakan dan mengukur ketrampilan, pengetahuan, intelegensi, kemampuan atau bakat yang dimiliki oleh individu/kelompok (Arikunto, 1997:29).

2) Observasi

Teknik Observasi dalam penelitian ini adalah mengamati secara langsung dengan teliti, cermat, hati-hati terhadap fenomena dalam pembelajaran Bahasa Arab pada kelas IV DTA Manaarul Huda Semester II Tahun Pelajaran 2019/2020 melalui media "Flashcard".

3) Dokumen

Dokumentasi dalam penelitian ini adalah berupa foto, data nilai hasil belajar siswa dalam pembelajaran Bahasa Arab Materi An-Nazah pada kelas IV Semester II DTA Manaarul Huda Tahun Pelajaran 2019/2020 melalui media "Flashcad".

\section{Prosedur Penelitian}

Prosedur penelitian tindakan ini dilakukan ke dalam empat tahapan tersebut. Adapun siklus yang dilakukan dalam penelitian ini adalah dua siklus. Desain penelitian tindakan kelas yang dinilai akurat dalam mencapai tujuan tersebut adalah model desain alur dari Kemmis dan Taggart yang memiliki ciri khas menggunakan model siklus. Setiap siklus terdiri dari dua atau tiga tindakan pembelajaran, sedangkan setiap tindakan 
pembelajaran mencakup empat tahapan kegiatan, yaitu perencanaan, pelaksanaan tindakan, observasi, dan refleksi-evaluasi. ${ }^{11}$

\section{Tindakan Siklus I}

\section{Perencanaan}

Kegiatan yang dilakukan dalam perencanaan meliputi sebagai berikut: 1) Guru melakukan identifikasi terhadap permasalahan; 2) Guru menyusun Rencana Pelaksanaan Pembelajaran (RPP); 3) Guru mempersiapkan materi pembelajaran; 4) Guru menyusun skenario pembelajaran media flashcard; 5) Menyiapkan sarana dan prasarana pembelajaran yang mendukung terlaksananya tindakan pembelajaran seperti tata letak meja belajar untuk belajar interaktif, menyiapkan buku sumber rujukan yang relevan dengan materi pembelajaran, dan lain sebagainya; 6) Menyiapkan instrumen observasi berupa instrumen pengamatan aktivitas belajar siswa dan tes hasil belajar; 7) Guru dengan kolaborator membahas dan mendeskripsikan secara jelas peran guru sebagai fasilitator pembelajaran tindakan, sebagai pengamat, dan sebagai evaluator; dan 8)Guru dengan kolaborator melaksanakan simulasi pelaksanaan tindakan dan menguji keterlaksanaannya di lapangan.

\section{Pelaksanaan}

Pelaksanaan pembelajaran Bahasa Arab dengan penerapan media flashcard dilaksanakan sebagai berikut: 1) Guru memberikan apersepsi tentang materi yang akan dijelaskan dan menjelaskan materi "An-Nazah" 2) Guru memberikan kesempatan siswa bertanya; 3) Guru membagi siswa ke dalam 2 kelompok yang masing-masing terdiri dari 11 dan 11 orang orang siswa; 4) Guru memberikan pertanyaan melalui media flashcard; 5) Siswa menjawab pertanyaan flashcard dengan system siapa cepat dia menang.

\section{Observasi}

Kegiatan pengamatan dalam pembelajaran Bahasa Arab dengan penerapan media "Flashcard" dilaksanakan sebagai berikut: 1) Kolaborator melakukan pengamatan terhadap kinerja siswa dalam kelompok serta kinerja guru dalam pembelajaran; dan 2) 2006), 65

${ }^{11}$ Wiriaatmadja, R., Metode Penelitian Tindakan Kelas (Bandung: PT. Remaja Rosdakarya, 
Kalamuna, Vol. 2. No. 1 Januari 2021. $24-36$

Guru dan kolaborator mempersiapkan instrumen berupa tes untuk penugasan secara individual.

\section{Refleksi Hasil Tindakan}

Refleksi dilakukan untuk mengetahui hasil pelaksanaan pembelajaran Siklus I. Kekurangan yang ada pada tindakan pembelajaran Siklus I dipergunakan sebagai bahan perbaikan untuk tindakan pembelajaran Siklus II.

\section{Tindakan Siklus II}

Tahapan yang dilakukan pada tindakan pembelajaran Siklus II sama dengan apa yang dilakukan pada tindakan pembelajaran Siklus I. Perencanaan dalam tindakan pembelajaran Siklus II dilakukan dengan memperhatikan hasil refleksi dari tindakan pembelajaran Siklus I.

\section{HASIL PENELITIAN}

\section{a. Aktivitas Belajar Siswa}

Hipotesis tindakan yang menyatakan bahwa "media flashcard dapat meningkatkan aktivitas belajar siswa dalam pembelajaran Bahasa Arab" terbukti kebenarannya. Hal ini ditunjukkan dengan meningkatnya aktivitas belajar siswa pada setiap siklus tindakan yang dilakukan.

Hasil pengamatan terhadap aktivitas belajar siswa pada kondisi awal menunjukkan bahwa sebagian besar siswa terlihat pasif dalam kegiatan pembelajaran sebelum dilakukannya tindakan. Hal ini menjadi dasar dilakukannya tindakan perbaikan pembelajaran dengan fokus meningkatkan aktivitas siswa dalam pembelajaran.

Tindakan perbaikan yang dilakukan guru dengan menerapkan media Flashcard dalam pembelajaran Bahasa Arab berhasil meningkatkan aktivitas siswa dalam pembelajaran. Hal ini ditunjukkan dengan meningkatnya jumlah siswa dengan aktivitas belajar kategori aktif pada setiap siklus tindakan yang dilakukan. Data peningkatan aktivitas belajar siswa dari kondisi awal hingga tindakan Siklus II dapat disajikan ke dalam tabel berikut ini.

\section{Tabel 1}

Peningkatan Aktivitas Belajar Siswa dari Kondisi Awal hingga Tindakan Siklus II 


\begin{tabular}{|c|c|c|c|c|c|c|c|}
\hline \multirow{2}{*}{ No } & \multirow{2}{*}{ Kegiatan } & \multicolumn{2}{|c|}{ Kondisi Awal } & \multicolumn{2}{|c|}{ Siklus I } & \multicolumn{2}{|c|}{ Siklus II } \\
\hline & & Jumlah & $\%$ & Jumlah & $\%$ & Jumlah & $\%$ \\
\hline 1 & $\begin{array}{l}\text { Aktif (skor } \\
27-36 \text { ) }\end{array}$ & 5 & $22.73 \%$ & 9 & $40.91 \%$ & 13 & $59.09 \%$ \\
\hline 2 & $\begin{array}{l}\text { Cukup Aktif } \\
\text { (skor 17-26) }\end{array}$ & 7 & $31.82 \%$ & 8 & $36.36 \%$ & 7 & $31.82 \%$ \\
\hline 3 & $\begin{array}{l}\text { Kurang } \\
\text { Aktif (skor } \\
9-16 \text { ) }\end{array}$ & 10 & $45.45 \%$ & 5 & $22.73 \%$ & 2 & $9.09 \%$ \\
\hline & Jumlah & 22 & $100.00 \%$ & 22 & $100.00 \%$ & 22 & $100.00 \%$ \\
\hline
\end{tabular}

Data peningkatan aktivitas belajar siswa dari kondisi awal hingga tindakan Siklus II dapat disajikan ke dalam diagram berikut ini.

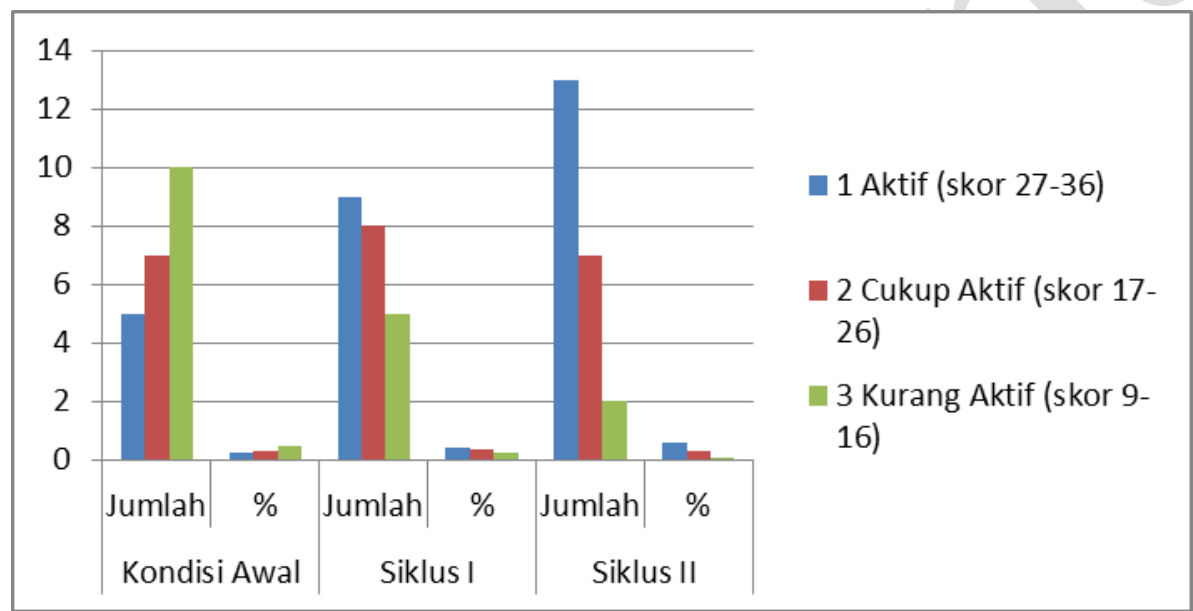

Faktor-faktor yang mempengaruhi aktivitas belajar siswa berupa faktor yang ada dalam diri siswa (internal) dan faktor yang berasal dari luar dari siswa (eksternal). Terkait dengan aktivitas belajar tersebut, Harmer menjelaskan bahwa aktivitas belajar berkaitan dengan mengenai adanya motivasi, baik motivasi intrinsik maupun ekstrinsik. Menurut Harmer dikatakan bahwa "intrinsic motivation consists of learning for personal reasons as an end in itself, whereas extrinsic motivation stems from a desire for an external reward". ${ }^{12}$ Demikian pula dalam hal pembelajaran sejarah, keberhasilan sangat ditentukan oleh adanya motivasi intrinsik dan ekstrinsik yang ada pada diri siswa.

Dorongan yang diberikan guru dapat menciptakan keberanian dalam diri siswa untuk berinteraksi dalam pembelajaran dan meningkatkan rasa percaya diri siswa. Hal

\footnotetext{
${ }^{12}$ Harmer, J., The Practice of English Language Teaching (London: Pearson Education Limited, 2005), 14
} 
ini dapat mendorong adanya keinginan untuk melakukan suatu usaha dengan melakukan latihan dalam proses belajar pada diri siswa. Dengan demikian maka aktivitas belajar siswa semakin meningkat dalam proses pembelajaran. Meningkatnya aktivitas belajar tersebut pada gilirannya dapat meningkatkan prestasi belajar siswa.

\section{b. Hasil Belajar Siswa}

Hipotesis tindakan yang menyatakan bahwa "Penerapan media Flashcard dapat meningkatkan hasil belajar siswa dalam pembelajaran Bahasa Arab materi An-Nazah kelas IV DTA semester II DTA Manaarul Huda tahun pelajaran 2019/2020” terbukti kebenarannya. Hal ini ditunjukkan dengan meningkatnya tingkat ketuntasan belajar siswa pada setiap siklus tindakan yang dilakukan.

Tingkat ketuntasan belajar siswa pada tahap awal sebelum dilakukannya tindakan pembelajaran adalah sebesar $45.45 \%$. Tingkat ketuntasan belajar siswa pada akhir tindakan pembelajaran Siklus I mengalami peningkatan menjadi 68.18\%. Tingkat ketuntasan belajar siswa tersebut mengalami peningkatan menjadi $100.00 \%$ pada akhir tindakan pembelajaran Siklus II.

Data peningkatan tingkat ketuntasan belajar pembelajaran dari tahap awal hingga akhir tindakan pembelajaran Siklus II dapat disajikan ke dalam tabel berikut.

Tabel 2

Peningkatan Ketuntasan Belajar Siswa dari Kondisi Awal hingga Tindakan Pembelajaran Siklus II

\begin{tabular}{|r|l|r|c|r|r|r|r|}
\hline \multirow{2}{*}{ No } & \multirow{2}{*}{ Ketuntasan } & \multicolumn{2}{|c|}{ Kondisi Awal } & \multicolumn{2}{c|}{ Siklus I } & \multicolumn{2}{c|}{ Siklus I } \\
\cline { 2 - 8 } & & Jumlah & \% & Jumlah & \% & Jumlah & \multicolumn{1}{c|}{$\%$} \\
\hline 1 & Tuntas & 10 & $45.45 \%$ & 15 & $68.18 \%$ & 22 & $100.00 \%$ \\
\hline 2 & Belum & 12 & $54.55 \%$ & 7 & $31.82 \%$ & 0 & $0.00 \%$ \\
\hline \multicolumn{2}{|c|}{ Jumlah } & 22 & $100.00 \%$ & 22 & $100.00 \%$ & 22 & $100.00 \%$ \\
\hline
\end{tabular}

Perkembangan tingkat ketuntasan belajar siswa pada setiap siklus tindakan yang dilakukan dapat disajikan ke dalam diagram sebagai berikut. 


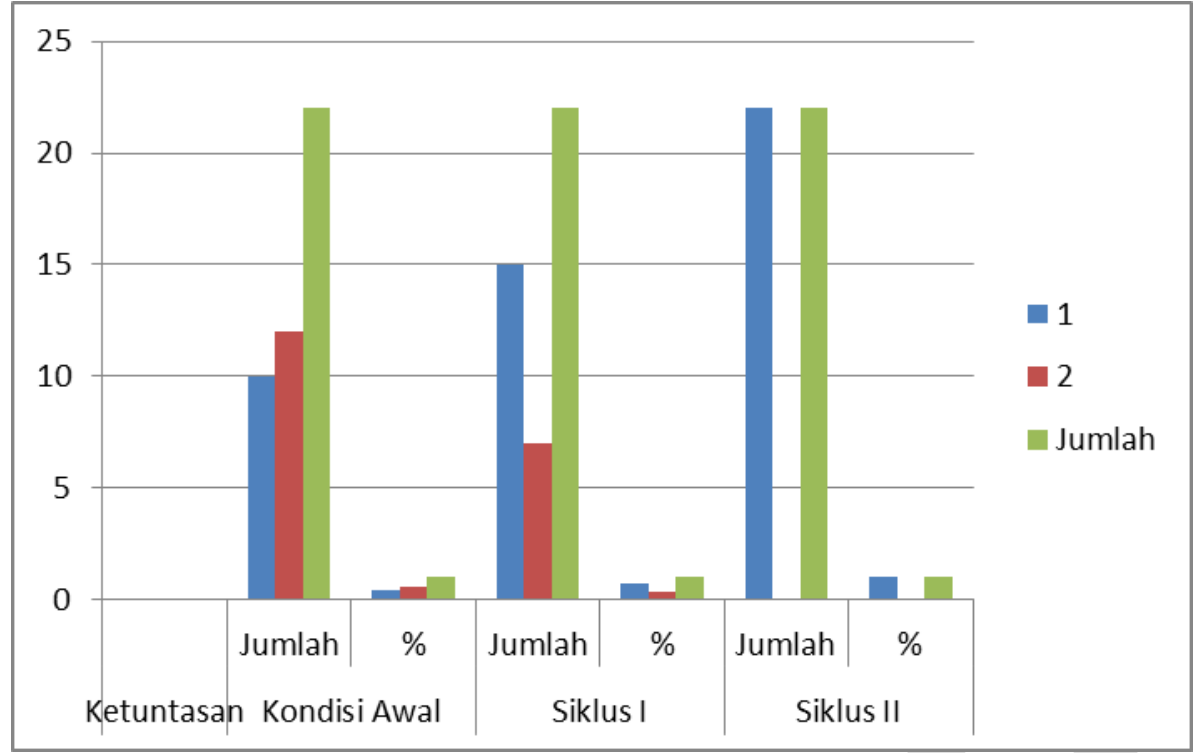

\section{E. PENUTUP}

Berdasarkan temuan-temuan penelitian dan analisis, maka selanjutnya dapat diperoleh kesimpulan sebagai berikut:

1. Penerapan media Flashcard dapat meningkatkan aktivitas belajar siswa dalam pembelajaran Bahasa Arab. Hal ini ditunjukkan dengan meningkatnya aktivitas belajar siswa pada setiap siklus tindakan yang dilakukan. Jumlah siswa dengan aktivitas belajar kategori aktif mengalami peningkatan dari sebesar $22.73 \%$ pada kondisi awal, meningkat menjadi $40.91 \%$ pada tindakan Siklus I, kemudian meningkat menjadi $59.09 \%$ pada tindakan Siklus II.

2. Penerapan media Flashcard dapat meningkatkan hasil belajar siswa dalam pembelajaran Bahasa Arab materi An-Nazah bagi siswa kelas IV semester II DTA Manaarul Huda tahun pelajaran 2019/2020. Hal ini ditunjukkan dengan meningkatnya ketuntasan belajar siswa pada setiap siklus tindakan yang dilakukan.

\section{DAFTAR PUSTAKA}

Hermawan, Acep. 2008. Metodologi Pembelajaran Bahasa Arab. Jakarta.

Susanto, Ahmad. 2012. Perkembangan Anak Usia Dini. Jakarta:Kencana.

Aqib, Zainal dkk. 2011. Penelitian Tindakan Kelas untuk guru SMP,SMA,SMK.

Bandung:CV. Yrama Widya 
Kalamuna, Vol. 2. No. 1 Januari 2021.24-36

Susilana, Rudi dan riyana, Cepi. 2009. Media Pembelajaran. Bandung:CV Wacana Prima.

Arsyad, Azhar. 2017. Media Pembelajaran. Jakarta:Rajawali.

Izzan, Ahmad. 2009. Metodologi Pembelajaran Bahasa Arab. Bandung:Humaniora.

Wiriaatmadja, R. 2006. Metode Penelitian Tindakan Kelas. Bandung: PT. Remaja Rosdakarya

Harmer, J. 2005. The Practice of English Language Teaching. London: Pearson Education Limited.

Permadi, D. dan Suryana, N. 2000. Pendekatan, Metode, Tehnik dan ModelPembelajaran Bahasa Inggris di SD dan MI. Bandung: Sarana Panca Karya 